\title{
Paul Clements, The Outsider, Art and Humour
}

\author{
Barry Mauer \\ University of Central Florida
}

Paul Clements. The Outsider, Art and Humour. Routledge, 2020. 215 pages.

You know what's funny? A mass-death pandemic and fascist insurrection, amirite? Ludicrously, our collective fate is tied to millions of people ( ${ }^{*}$ cough* $^{*}$ Republicans ${ }^{*}{ }$ cough ${ }^{*}$ ) trapped in a murder-suicide cult who believe absurdities and commit atrocities. Can art and humor save us by mocking the perpetrators, leading us to justice, and lightening our hearts? Maybe. Maybe not.

Paul Clements' The Outsider, Art and Humour is about the pain of exclusion (and also the freedom that can come from it), the ways people use art and humor to keep others out, and the ways outsiders use art and humor to fight back. We "get it" when we are in on the art, the joke, or the art-joke, and we "get it" when we are not in on the joke or are the subject of punishing ridicule and exclusion. Art and humor are and always have been caught up in power struggles that shape and reshape society. But narrating this struggle, and the ways that art and humor function in it, is anything but easy.

Clements shows us why humor and joking in art, and in particular "outsider art," should matter to us. His book is funny, and he explains the jokes, yet it is serious because humor can heal or abuse and we ought to care whether it makes people's lives better or worse. As Clements notes, "Jokes arise out of the inequalities of social structure, where racial, sexual and gendered humour operates to reproduce these, but also to question them. Humour reflects and reinforces the contradictions of humanity as it creates and dissolves tensions, conforms to and critiques existing systems, hence its Janus-like character. Nonetheless, it is easy to denigrate the weak and vulnerable but far more difficult to hold those with power to account and to poke fun at them" (22).

The outsider, art, and humor are very broad and messy categories. "There is broad definition of the labels 'art' and 'artist' in this book, which are situated as inclusive phenomena that bridge a range of visual, oral and written texts as well as musical, filmic and performed cultures. Marginal Art and marginal artists are terms employed to cover a wide gamut of outsider, folk, self-taught, visionary art forms and creative producers" (10). Human beings know tragedy well enough (thanks, ye gods! . . . and Aristotle!). But, as Samuel Johnson wrote, "comedy has been unpropitious to definers." Clements thus must deal with the wide array of comic types. For example, he identifies "three overlapping comic categories: the clownish and slapstick . . . burlesque . . . and the grotesque." Instead of a unified theory of humor and comedy, we have to contend with a variety of theories: Superiority Theory, Relief (or Release) Theory, Incongruity Theory, Play Theory, Dispositional Theory, and Social Exchange Theory (17-23). 
Humor also has many functions; it can get us into a jam or out of a jam. It can be reactionary, aggressive, radical, or loving. Ambiguities and undecidability abound, "In general, there appears to be a lack of consistency (and definition) regarding the highly nuanced character of humour that is able to capture its relationship to taste, both politically correct ideal and incorrect reality, positive or negative tone, radical or reactionary practice" (29). Clements adds, "Humour is a powerful social, cultural and political tool, although there is always a degree of ambiguity regarding meaning or morality and how this functions in practice" (30).

Just as humor has many variants, so does outsiderdom. Clements writes, "Three overlapping models of marginal art are detailed and evaluated, that of Outsider Art (Dubuffet, Cardinal, Maizels and Wojcik), Welfare Art (Levine and Clements) and Savant Art (Sacks and Pring et al.), which includes criticisms of the discourse of Outsider Art (Ames, Prinz and Dubin). A wider historical overview of carnivalesque places and practices situated in omnivorous taste is further explored, as is how heterogeneity creates degrees of dissonance (Lahire)" (109). Outsiderdom can result from "self-definition, lack of integration, marginalization, poverty, alienation and madness amongst other discourses" (45). Clements adds more categories of outsiderdom such as freak, prisoner, creative madness, and outsider hip. Additionally, he writes, "The excluded 'other' is shaped by powerlessness reinforced through superior notions of reactionary humour (Critchley), anomie (Durkheim) and alienation (Marx) driven by lack of cultural capital (Bourdieu)" (45). Since exclusion shapes institutions and our identities, we need to understand what it is and how it works. Clements' book greatly increases our understanding of exclusion as it shapes, and is shaped, by art and humor.

The boundary between inclusion and exclusion in the art world is controlled by gatekeepers. The category of "Outsider Art" has created a paradox, however, one in which gatekeepers select a few artists from the margins and put their work in front of people with influence and money, making these artists, in some ways, insiders. Clements writes of the artist Albert Louden,

He was a self-taught artist who acquired 'star' outsider artist status with a biography of obsessiveness testimony to his compulsive need to paint, and was later championed then rejected by specialist Outsider Art galleries (and later re-appropriated (Windsor 1997; 110 Representations by Marginal Artists Rhodes 2000)). John Windsor has suggested that he was a casualty of Outsider Art orthodoxy precisely because he was not incarcerated and was able to hold down a job as a van driver. . . his interest in his own career badly affected his reputation as it contradicted the 'authentic' stereotype of outsider as a dysfunctional narcissist and unambitious artist. Initially, after visiting the Outsider Art exhibition in London (Hayward Gallery 1979), he approached the dealer and collector Victor Musgrave, a doyen of Outsider Art who was enthusiastic about his work. He selfconsciously built up his reputation, which included a one-man show in London at the Serpentine Gallery (Louden 1985).

Colin Rhodes (2000: 20) explained:

At this point Louden found himself subject to the fate of many marginal artists; as he seemingly 'came in' from the outside, his old support dwindled, whilst mainstream acceptance failed to materialize ... his critics argued conveniently that his interest in his own success was deemed to have adversely affected the quality of his production.

... Whether his success or commercial attitude de-authenticates his art is a point of debate. (110-11)

When you're out you're in, and when you're in you're out . . . how funny! Clements' qualifications to weigh in on these matters come from years of experience working at the intersection of academia, social service (in prisons for example), and art (as a visual artist himself). His writes passionately and organizes his themes into a big 
picture while presenting fascinating cases along the way. His review of literature about humor is worth the price of admission alone. Clements has a warm and compassionate tone; he respects the lives, and the humor and art, of those who have been severely marginalized.

Clements' presentation is straightforward and reader-friendly, with overviews of relevant theories and case studies. His conclusion? That our primary categories - art, outsiderdom, and humor - are unstable: "My original intention of employing humour as a method to better understand representations of the outsider and exclusion through the visual arts in particular has reaffirmed the complexity of meaning. Four changeable variables that exacerbate this beyond individual and group tastes are: the unstable (self-) definition of outsider; the extent of alienation of marginal artists; the ramifications and unpredictability of humour styles; and cultural recuperation" (184). Rather than feel dissatisfied with my now-heightened awareness of instability and complexity, I am grateful to know more about why humor and the arts resist easy answers.

The subjects that Clements addresses here call for further study. For instance, he touches on the roles of humor and art in different regimes such as capitalist, fascist, and communist ones. Here's a joke he cites; "Is it true that Comrade Stalin collects political jokes? Yes, but first he collects the people who tell them" (32). Nazi humor consists mostly of racist ridicule aimed at "degenerates" (89-90). But such humor, if you can call it that, is thriving in the USA. As I wrote in Deadly Delusions: Right-Wing Death Cult:

Trump likes to say he is "joking" when he calls his followers to violence. Such "jokes," which are always cruel but never funny, are part of the way right wing leaders normalize dehumanization and violence. For Trump's followers, cruelty - not tax cuts or regulation - is the most important policy. The joking, a form of trolling, is how one joins and participates in this cult. "Joking" is part of a larger right-wing strategy of deniability, which includes obscuring the motives of the murderers.

Capitalism, as we already know, commodifies art and humor. Clements usefully points to the quantity of "dark matter" that makes it possible for a few people to profit at the expense of the many. "The mass of unsuccessful and excluded creators of art (the producers of 'dark matter') are vital for the success of the few as they comprise the audience and customers for art and its merchandising, which hierarchical and pyramidal logic befits that of commodity capitalism and competitive celebrity" (76). Marx, in Capital, drew attention to the diamond miners who didn't find diamonds; they were still part of the average labor cost accrued per diamond. We could say the same goes for all the people who make jokes and art that don't sell.

Understanding the outsider, art, and humor in different regimes, such as capitalist, fascist, and Stalinist, can help us better understand their malleability. The avant-garde movements in the 1920s and 1930s, for instance, were alternately suppressed and encouraged in all three systems. Hollywood hired all the avant-gardists it could, not knowing how they might contribute to their profit margins but wanting to capture their potential. While Hitler's and Stalin's regimes both suppressed the avant-garde, Italian and Russian Futurists had served as these regimes' precursors and gave energy to their early successes.

One way Clements might continue his work on the boundaries of insider/outsider is to frame the issue using Julia Kristeva's notion of abjection. Greg Ulmer combines Kristeva's notions with those of Georges Bataille, framing the abject as the excluded waste products that result from our habits. In this sense, the outsider - the prisoners, the Nazis, the homeless - are society's waste, its (normally) excluded part. Some people exclude themselves because they are repulsed by official values or are attracted to the margins. Sometimes, like now, unwelcome parts of the 
margin move to the center. As Clements notes, "In democratic societies, outsiders may be tolerated however much they are vilified, whether revolutionary communists, pickpockets, eco-warriors, asylum seekers or those with extreme far-right views" (45).

In the USA, the fascist fringe is no longer a fringe because it is embraced by the center of the Republican Party, with openly-insurrectionist leaders like Ted Cruz, Josh Hawley, Lauren Boebert, and Marjorie Taylor Greene holding power. None of these people deserve to be called artists and they are about as funny as a turd in the punch bowl. But their ascendance upsets the binaries of insider and outsider. Clements writes, "far-right political and fundamentalist religious groups have little interest in finding common ground, empathy or difference, let alone people's laughter" (82). While far-right figures frame their identities by unjustly excluding others - liberals, foreigner, LGBTQ, racial minorities, etc. - such open and obnoxious fascism has been excluded at times, and for good reason because it should be excluded.

Mental illness is another category of exclusion, with its own resulting humor and art. Clements writes,

Goffman (1991 [1961]) defined mental illness as a social phenomenon and construct rather than an individualized psychological and medical phenomenon. He (1991: 23-72) described the patient in an asylum as an excluded outsider dominated and controlled by the overbearing character of the total institution, which 'institutionalization' contributes to the problems of inclusion outside this domain. The asylum frames and structures experience for the inmates, which helps to dissipate their identities as the institutional world imposes 'disculturation' and 'untraining' on them and they are unable to manage 'normal' everyday life. But one way in which inmates in psychiatric hospitals and prisons escape these institutional frameworks and regain a sense of their former selves and identities is through informal communication networks and humour" (64).

The labeling, exclusion, and stigma associated with mental illness has resulted in the marginalization and punishment of people with mental health problems, in ill people refusing treatment, and in a backlash against the medical field for defining and pathologizing people based on normative values and behaviors. We do not need to romanticize mental illness, as Jean Dubuffet did with his championing of Raw Art, and we do not need to victimize mentally-ill people as the Nazis did. But in general, people who are free from mental illnesses (as we commonly understand them) are better off. In general, people with mental illnesses are not dangerous and are often victims. In general, it is better that people with mental illnesses receive proper treatment to reduce their suffering. In general, our society is safer when we monitor people with particularly dangerous mental illnesses, such as violent psychopathy. The term "in general," if applied wisely, could help us to make reasonable distinctions between outsiders who should be included and those who should be excluded. The regulation of inclusion and exclusion is not necessarily a bad thing and Clements' work could be extended into further discussion of such ethical considerations.

The often-extreme conditions in which outsider art is born produces light and dark humor. Clements appreciates both. "It is dark humour in particular," Clements writes, "that unearths the hidden issues and presents a mirror to society that is unsettling but vitally important" (184). A critically important dark type is gallows humor, which occurs, as we might expect, in prisons and other places where dehumanization is a common experience. Light humor can still be serious. Clements discusses The Clandestine Insurgent Rebel Clown Army (CIRCA), which challenges the authority of military and capitalist mis-rule. "Members of this 'army' paint themselves up as clowns and wear brightly coloured clothing, including standard army camouflage, colanders for hats, clownish uniforms and other ridiculous paraphernalia" (175). Clements continues, "The clowns push until they get a reaction, then they draw back... The resulting 'ethical spectacle' (Duncombe 2007) and tension more often than not confronts 
the viewer as it mocks authority and disrupts normalcy, creating degrees of disruption. This kind of playful activism relies on tactics of surprise and gesture, which enables an inversion of mundane reality through the anarchic treatment of power relations (Clements 2017a: 191)" (176).

While reading Clements' book, I expected a discussion of work by Victor Shklovsky and Bertolt Brecht, which argues that defamiliarization (Shklovsky) or the Alienation-Effect (Brecht) can be strategies of art, but are not tactics. Tactics that defamiliarize or alienate eventually become old hat; thus, art and humor need freshness. Shklovsky and Brecht might help us better understand the shifting landscape that Clements presents of the outsider, art, and humor and why things that are out become in and vise verse.

Clements addresses these issues in his own terms:

The importance of chaos and the randomness of systems, social processes and practices cannot be underestimated. Creative expression through art and humour articulates non-linearity, which, without venturing into extra-sensory perception and occult weirdness, fractures and discombobulates those 'rational' systems and discourses imposed from above that entrap our minds and sensibilities (including language). The importance of incongruous humour is precisely because it offers a critique of repetitive habit, restricted thinking and a perfect digitally constructed world of algorithms and meanings. Politically, resistant art is vital; whether artivists demonstrating against corporate and state hegemony, grotesque realists graphically detailing bodily 'imperfection', caricaturists besmirching privilege and cosy establishment arrangements, satirists lampooning hubris through scatological comedy, or transgressive graffiti artists who détourne language. These are a crucial riposte to networked 'insider' art worlds and established hierarchies, however much these humorous, creative individual and collective voices from the periphery are subsequently recuperated through aesthetic laundering of the 'dirty' and authentic. (185)

Clements' book raised numerous questions that future researchers ought to address. For instance, what about memes? Clements never mentions them, though he briefly mentions digital technologies of reproduction and distribution. How do memes alter our understanding of the outsider, art, and humor? The internet is perhaps the most significant information technology to come along since the printing press and, according to theorists like Gregory Ulmer, it represents a new apparatus (a social machine involving inventions in technology, institutional practices, and identity formation). We could posit that the $20^{\text {th }}$ century avant-garde movements from dada to Fluxus were developing the practices in logic and networking that would become native to the internet. The internet is a site of battle over inclusion and exclusion where people use art and humor to define themselves and others. What is becoming of the outsider in the internet age?

The avant-garde often employed humor in their art and politics. But despite, or maybe because of, its history, Clements is not very optimistic about the power of outsider art and humor to change the world.

In this era of 'fake news' and disinformation, truth is a casualty alongside objectivity, taste and critical engagement. Humour is an apt leveller and, like art, can rein back humbug, dubious sentiment and gross distortion. It is highly unlikely that humorous art will change the world and it is impossible to predict when it will realize the latent social and political impact it can have. There is no certainty of comic or aesthetic representation or effect ... (185)

Clements critiques the commercial exploitation of outsider art, arguing that it neutralizes the threat such art poses to the status quo. He also critiques the artists who create work that is too easily exploited. "Over the past 100 years or so anti-art practices have been accompanied by greater autonomy, doubt over categorizations and a refusal to conform to expectations (in many ways encapsulated by 'the shock of the new' idea underpinning modern art). This has played into the hands of the markets and the fetishization of individual artists as brands, whilst the marginal artist appears to transgress the mainstream and its networks, which appears authentic. But 
this is a very unstable position to maintain and marginal artists often are forgotten, assimilated as aesthetic commodity or ridiculed as kitsch." (132). While I am sympathetic to this argument, I also agree with Robert B. Ray, who points out that the history of appropriation is not only about defusing threats to power but also about recognizing usefulness.

\begin{abstract}
... to assume that increasingly rapid co-option will destroy the avant-garde ignores how much the avant-garde itself has, throughout its history, promoted its own acceptance. From the start, its preferred analogy was to science, where the route from pure research to applied technology is not only a matter of course, but also a raison d'etre for the whole enterprise. From this perspective, the avant-gardist's typical complaint about assimilation seems misguided. When the Clash's Joe Strummer denounced fraternity parties' use of "Rock the Casbah" as mindless dance music, he seemed like a chemist protesting the use of his ideas for something as ordinary (and useful) as, let us say, laundry detergent.
\end{abstract}

The Impressionists, on the other hand, the first avant-garde, understood almost immediately that assimilation was a necessary goal. (75)

Greg Ulmer's popcycle models the circulation of ideas across various apparatuses. Some ideas that start in marginal places, such as the avant-garde, in folk art, or in street culture, get picked up and circulated in other institutions (like education and entertainment). Jazz, for example, was street music in segregated black communities. Then it became commercial mass entertainment. Then scholars such as Cornel West adopted jazz as a method of knowledge. In each case, jazz serves different functions in different institutions. Each appropriation of jazz effaces some of its practices and effects while activating others. Jazz has authentic connections to its original milieu, but is useful in ways that its inventors could not have imagined.

The one complaint I have about Clements's book is that it refers to Craig Saper as Craig Sapper. Since it was Craig who asked me to do this review, the error is particularly ironic. But maybe Sapper is the correct British spelling! I didn't see any other errors in the book.

When reading Clements' comments about humor and superiority, I felt a sting of recognition; the jokes I heard and repeated as a white kid in a white suburb in Minnesota in the 1970s were aimed at women, minorities, foreigners, the disabled, and anyone different from me. I remember the shock I felt, once my family moved to a big city, the first time an adult took offense to such "jokes." It created a perspectival shift; jokes were not "harmless," but were weapons. When it comes to my use of art and humor as an adult, I am by no means a pacifist but I try to choose my targets wisely and take better aim. Clements' book is a great primer for scholars, jokers, and artists who seek justice in a crazy world.

\title{
Works Cited
}

Mauer, Barry. Deadly Delusions: Right-Wing Death Cult. (Orlando, FI: The Governors of the State of Florida Press, 2020).

Ray, Robert. "How to Start an Avant-Garde," How a Film Theory Got Lost and Other Mysteries in Cultural Studies, (Bloomington: Indiana University Press, 2001). 
Ulmer, Gregory. Heuretics: The Logic of Invention. (Baltimore, MD: John Hopkins University Press, 1994).

\section{Cite this Review}

Mauer, Barry. "Paul Clements, The Outsider, Art and Humour." Rhizomes: Cultural Studies in Emerging Knowledge, no. 37, 2021, doi:10.20415/rhiz/037.r02

RHIZOMES ISSN 1555-9998 \ 230 East Hall Bowling Green State University Bowling Green, OH 43403

Editors: Ellen Berry and Carol Siegel. Reviews editor: Craig J. Saper. Technical editor: Helen J Burgess 